\title{
Forage potential and silage quality of four varieties of saccharine sorghum
}

\author{
Marco Antonio Previdelli Orrico Junior( ${ }^{(1)}$, Marciana Retore ${ }^{(2)}$, Débora Maurício Manarelli(1), \\ Fernanda Barboza de Souza ${ }^{(3)}$, Luana Liz Medina Ledesma ${ }^{(4)}$ and Ana Carolina Amorim Orrico ${ }^{(1)}$
}

\begin{abstract}
(1)Universidade Federal da Grande Dourados, Faculdade de Ciências Agrárias, Rodovia Dourados-Itahum, Km 12, s/no, Cidade Universitária, CEP 79804-970 Dourados, MS, Brazil. E-mail: marcojunior@ufgd.edu.br, debora_manarelli@hotmail.com, anaorrico@ufgd.edu.br (2)Embrapa Agropecuária Oeste, Rodovia BR 163, Km 253,6, Caixa Postal 449, CEP 79804-970 Dourados, MS, Brazil. E-mail: marciana.retore@embrapa.br (3)Universidade Estadual de Mato Grosso do Sul, Rodovia Dourados-Itahum, Km 12, Cidade Universitária, CEP $79804-970$ Dourados, MS, Brazil. E-mail: fernanda_barbozza@yahoo.com.br ${ }^{(4)}$ Instituto Federal de Mato Grosso do Sul, Campus Ponta Porã, Rodovia BR-463, Km 14, s/no, CEP 79909-000 Ponta Porã, MS, Brazil. E-mail: luanaliz2009@hotmail.com
\end{abstract}

\begin{abstract}
The objective of this work was to evaluate four cultivars of saccharine sorghum (Sorghum bicolor) regarding productivity, chemical composition of plant parts, and quality of the ensiling process. The tested varieties of saccharine sorghum were BRS 506, BRS 508, BRS 509, and BRS 511. The experiment was divided into two trials, which assessed: production, morphological composition, and nutritional quality of the saccharine varieties; and fermentation quality and nutritional value of the silage produced from the saccharine varieties. Of the tested varieties, BRS 509 and BRS 511 showed the highest total dry matter (DM) production. The BRS 508 variety presented the highest in vitro digestibility of the whole plant $(70.65 \% \mathrm{DM})$. During ensiling, the BRS 509 variety showed the lowest DM loss $(8.87 \%)$. The highest effluent production was observed for BRS 506 and BRS 508, with yields of 521.87 and $393.16 \mathrm{~kg} \mathrm{Mg}^{-1}$ ensiled DM, respectively. The BRS 511 variety is the most recommended because of the best results for plant production and nutritional quality. Regarding the ensiling process, BRS 509 presents the lowest fermentation losses and the highest nutritional value of silage.
\end{abstract}

Index terms: Sorghum bicolor, forage system, nutritional value, roughage, ruminant.

\section{Potencial forrageiro e qualidade da silagem de quatro variedades de sorgo sacarino}

\begin{abstract}
Resumo - O objetivo deste trabalho foi avaliar quatro variedades de sorgo sacarino (Sorghum bicolor)quanto à produtividade, à composição química das partes da planta e à qualidade do processo de ensilagem. As variedades de sorgo sacarino utilizadas foram BRS 506, BRS 508, BRS 509 e BRS 511. O experimento foi dividido em dois ensaios, que avaliaram: produção, composição morfológica e qualidade nutricional das variedades sacarinas; e qualidade do processo fermentativo e valor nutricional das silagens das variedades sacarinas. Das variedades testadas, a BRS 509 e a BRS 511 foram as que apresentaram maiores produções de matéria seca (MS) total. A variedade BRS 508 apresentou o maior coeficiente de digestibilidade in vitro da planta inteira $(70,65 \%$ da MS). Durante a ensilagem, a variedade BRS 509 foi a que apresentou menor perda de MS (8,87\%). A maior produção de efluentes foi observada para BRS 506 e BRS 508, com produção de 521,87 e $393,16 \mathrm{~kg} \mathrm{Mg}^{-1} \mathrm{de}^{2}$ MS ensilada, respectivamente. A variedade BRS 511 é a mais indicada em razão dos melhores resultados de produção e de qualidade nutricional da planta. Em relação ao processo de ensilagem, a BRS 509 apresenta as menores perdas fermentativas e o maior valor nutritivo da silagem.
\end{abstract}

Termos para indexação: Sorghum bicolor, forragicultura, valor nutritivo, volumoso, ruminantes.

\section{Introduction}

In Brazil, the use of sorghum [Sorghum bicolor (L.) Moench] in animal feed has been growing every year, mainly due to its greater resistance to water stress when compared to corn (Alves et al., 2012). The development of a male-sterile line of grain sorghum allowed the generation of hybrids that are more suitable for silage production, with good dry matter yield and also high nutritional value (Souza et al., 2003; Nascimento et al., 2008).

Saccharine sorghum varieties, distinguished by increased stem yield and high content of soluble carbohydrates, were developed to be used as raw material for ethanol production in the off-season of sugarcane (Silva et al., 2014a). The BRS 506 variety 
was one of the first cultivars to be developed by Embrapa in the 1980s, and it became the main option for the production of ethanol at that time (Durães et al., 2012). In 2012, three new varieties were launched by Embrapa: BRS 508, BRS 509, and BRS 511, which are considered, so far, the best alternatives for cultivation, according to studies carried out by Parrella \& Schaffert (2012).

Although these varieties have been widely studied for ethanol production, little is still known about their potential as forages. Current studies, such as those of Lourenço et al. (2007) and Santos et al. (2015), only assess the sugar content and stem production of these varieties, without discussing the nutritional quality of different plant parts and its effect on silage production. Moreover, the large amount of sugar present in these varieties can provide a significant source of energy intake for animals, improving animal performance and contributing to the efficiency of the ensiling process (Bergamaschine et al., 2006; Coan et al., 2007; França et al., 2011). Amer et al. (2012) evaluated the performance of dairy cows fed with hybrid saccharine sorghum (CSSH45) and obtained average yields of $33 \mathrm{~kg}$ milk per day. This result indicates that further studies are needed to assess the nutritional value of the varieties of saccharine sorghum used in Brazil.

The objective of this work was to evaluate four cultivars of saccharine sorghum (Sorghum bicolor) regarding productivity, chemical composition of plant parts, and quality of the ensiling process.

\section{Materials and Methods}

The study was conducted at the experimental field of Embrapa Agropecuária Oeste, and chemical analysis was performed at Universidade Federal da Grande Dourados, both located in the municipality of Dourados, in the State of Mato Grosso do Sul, Brazil. The soil of the experimental area is classified as a Latossolo Vermelho-Escuro (Rhodic Oxisol) with clay texture (Santos et al., 2006), and presented the following characteristics: $\mathrm{pH}\left(\mathrm{CaCl}_{2}\right) 4.6 ; 24.4 \mathrm{mg} \mathrm{dm}^{-3} \mathrm{P}$-resin; $8.0 \mathrm{mmol} \mathrm{dm}^{-3} \mathrm{~K} ; 42 \mathrm{mmol} \mathrm{dm}^{-3} \mathrm{Ca} ; 17 \mathrm{mmol} \mathrm{dm}^{-3} \mathrm{Mg}$; $82 \mathrm{mmol} \mathrm{dm}^{-3} \mathrm{Al}+\mathrm{H}$; sum of bases of $244 \mathrm{mmol} \mathrm{dm}^{-3}$; cation exchange capacity of $149 \mathrm{mmol} \mathrm{dm}^{-3}$; base saturation of $44.9 \%$; and $30.6 \mathrm{~g} \mathrm{dm}^{-3}$ organic matter. The average temperature during the experimental period was $28.1{ }^{\circ} \mathrm{C}$, and the accumulated precipitation was $485.4 \mathrm{~mm}$.

The experiment was divided into two trials, which assessed: production, morphological composition, and nutritional quality of the saccharine varieties; and fermentation quality and nutritional value of the silage produced from the saccharine varieties.

The experiment was established in June 2014, considered as an "off-season" culture, in a randomized complete block design with four treatments (the saccharine sorghum varieties BRS 506, BRS 508, BRS 509, and BRS 511) and eight replicates. A total of $450 \mathrm{~kg} \mathrm{ha}^{-1}$ of the formula $8-20-20 \mathrm{~N}-\mathrm{P}_{2} \mathrm{O}_{5}-\mathrm{K}_{2} \mathrm{O}$ was applied at sowing, and nitrogen fertilization with $500 \mathrm{~kg}$ ammonium sulfate and $100 \mathrm{~kg} \mathrm{KCl}$ was applied 30 days after plant emergence. Sowing was performed using a planter, with $0.45 \mathrm{~m}$ between rows and seven plants per linear meter, totaling 155,000 plants per hectare. The experimental plots were eight 5.0-m long rows, excluding $1.0 \mathrm{~m}$ at each end.

Harvesting occurred when each hybrid reached $28 \%$ DM, i.e., when the grains are in the dough stage, which was at 138 days for BRS 506, 120 days for BRS 508, 132 days for BRS 509, and 132 days for BRS 511. The evaluated parameters were: production of dry matter per hectare, and the proportion of stem, leaves, and panicles in plants. Leaf fractions were separated into blade and sheath, whereas the panicle was detached at the insertion of the last leaf. The fractions were dried at $55^{\circ} \mathrm{C}$ in a forced air circulation drying oven for 72 hours and were then ground in a Willye-type mill, model STAR FT-50/6, (Fortinox, Piracicaba, SP, Brazil), with 1.0-mm mesh sieve, for laboratory analysis. The dried and ground samples were subjected to analyses of DM, crude protein (CP), neutral detergent fiber (NDF), acid detergent fiber (ADF), hemicellulose, cellulose, lignin, and in vitro DM digestibility (Silva \& Queiroz, 2006).

The results were evaluated through analysis of variance, and the means were compared by Tukey's test, at 5\% probability, using the $\mathrm{R}$ software (The $\mathrm{R}$ Foundation, 2012).

The experiment to evaluate silage fermentation quality and nutritional value was carried out in a completely randomized design with four treatments and six replicates (silos). The treatments were the varieties of saccharine sorghum: BRS 506, BRS 508, BRS 509, and BRS 511; and the experimental silos were made with PVC pipes, with $50 \mathrm{~cm}$ height and 
$10 \mathrm{~cm}$ diameter, sealed at the bottom end with a cap. At the bottom of the silos, $0.3 \mathrm{~kg}$ dry sand was placed, separated from the forage by a screen and a cotton fabric, to quantify the effluent produced. Compaction of the chopped material was performed manually with wooden bats. After compaction of forage, the silos were sealed with plastic sheet and duct tape, weighed, and stored.

At 100 days of fermentation, silos were weighed again to determine gas losses and were then opened. The determination of gas loss was calculated according to the following equation (Jobim et al., 2007): $\mathrm{GL}=(\mathrm{SWE}-\mathrm{SWO}) / \mathrm{EDM} \times 100$, in which $\mathrm{GL}$ represents gas losses (\% DM); SWE is the silo weight at ensiling $(\mathrm{kg})$; SWO is the silo weight at opening $(\mathrm{kg}$ ); and EDM is the ensiled DM (forage amount in $\mathrm{kg}$ $\times \% \mathrm{DM})$.

After silage removal, the set silo, sand, screen, and cotton fabric was weighed to quantify the amount of effluent produced. Effluent production was calculated through the equation (Jobim et al., 2007): $\mathrm{PE}=(\mathrm{WSSO}-\mathrm{WSSE}) / \mathrm{EDM} \times 1,000$, in which PE is the effluent production ( $\mathrm{kg}$ of effluent $/ \mathrm{Mg}$ ensiled green mass); WSSO is the weight of silo, sand, screen, and fabric after opening $(\mathrm{kg})$; WSSE is the weight of silo, sand, screen, and fabric before opening $(\mathrm{kg})$; and EDM is the ensiled DM (kg).

DM loss was determined by the following equation (Jobim et al., 2007): DM loss = ((DMi - DMf) /DMi) $\times 100$, in which DMf is the final amount of DM; and DMi is the initial amount of DM.

After opening, silage samples, of approximately $300 \mathrm{~g}$, were collected from each plot. Each sample was divided into two sub-samples: one was used for determination of $\mathrm{pH}$, according to Silva \& Queiroz (2006); and the other was weighed and taken to a forced air circulation drying oven, at $55^{\circ} \mathrm{C}$, for 72 hours and ground in a Willye-type mill, model STAR FT-50/6, (Fortinox, Piracicaba, SP, Brazil), with 1.0-mm mesh sieve, for further laboratory analysis.

The dried and ground samples were subjected to analysis of $\mathrm{DM}, \mathrm{CP}, \mathrm{NDF}, \mathrm{ADF}$, hemicellulose, cellulose, lignin, and in vitro DM digestibility (Silva \& Queiroz, 2006). The results were evaluated by analysis of variance, and the means were compared by Tukey's test, at 5\% probability, using the $\mathrm{R}$ software (The $\mathrm{R}$ Foundation, 2012).

\section{Results and Discussion}

Among the tested varieties, BRS 511 and BRS 509 presented the greatest values of total DM production, whereas BRS 508 had the worst performance for this parameter (Table 1). There was a difference in stem production among varieties, with a mean value of $19,679 \mathrm{~kg} \mathrm{ha}^{-1} \mathrm{DM}$. The BRS 508 variety also had the greatest leaf production (960.82 $\left.\mathrm{kg} \mathrm{ha}^{-1} \mathrm{DM}\right)$, which represents a ratio of 4.3 leaves in relation to the total DM production.

The stem was the part of the plant with the highest ratio and a mean value of $85.9 \%$ in the morphological composition of the evaluated varieties. This result was already expected since the saccharine varieties were selected for high stem production (Lourenço et al., 2007; Santos et al., 2015). There was no difference in the stem ratio among varieties; however, the high proportion of this fraction affected the results of chemical composition.

The CP content of the tested varieties was higher in the leaf fraction, with no significant differences among varieties (average of $11.10 \% \mathrm{CP}$ ). However, the CP content of the whole plant was higher in the BRS 508 and BRS 511 varieties. Rodrigues Filho et al. (2006) observed variations of CP content of 4.85 to $7.78 \%$ (average of $6.73 \% \mathrm{CP}$ ) in different varieties of forage sorghum, i.e., CMSXS 762, BRS 610, BR 700, and BRS 506. When comparing all tested varieties, only BRS 511 and BRS 508 presented a CP content similar to that of a forage variety - in this case BR 700 -, whereas the other varieties showed much lower CP values. Since protein is essential to meet the nutritional requirements of animals, when using saccharine sorghum in ruminant feed, larger ratios of protein concentrate in diets will be necessary to ensure minimum levels of protein.

The fibrous fractions were increased in the panicle due to the low production of grains (average of $2.4 \%$ DM of panicle), observed mainly in the BRS 506 and BRS 511 varieties. BRS 508 showed the highest coefficient of whole plant digestibility $(70.65 \% \mathrm{DM})$, which can be explained by the fact that this variety presented one of the largest $\mathrm{CP}$ contents, associated with one of the lowest NDF contents in the plant. Regardless of the fraction of the plant analyzed, the BRS 506 variety was the one that presented the highest levels of NDF, ADF, cellulose, and lignin, which influenced negatively in vitro digestibility of the plants.

Pesq. agropec. bras., Brasília, v.50, n.12, p.1201-1207, dez. 2015 DOI: 10.1590/S0100-204X2015001200010 
Orrico Junior et al. (2013) pointed out the importance of NDF to assess the quality of forage plants. According to this author, the higher the NDF ratio, the lower is the voluntary intake of forage by animals, and, as a result, the worse is animal performance. Therefore, the BRS 506 and BRS 509 varieties would be the least indicated for use in animal feed because of the low DM production and low nutritional quality of the plants.
A similar result was obtained by Rodrigues Filho et al. (2006), who compared the BRS 506 variety with BRS 610, BR 700, and CMSXS 762. These authors highlighted that BRS 506 presented the same productive potential as other varieties, but with lower levels of CP and total digestible nutrients. The BRS 511 variety had distinctive productions of panicle and stem, resulting in plants with lower fiber content and higher

Table 1. Production, chemical composition, and in vitro digestibility coefficient of panicle, leaf, stem, and whole plant from four varieties of saccharine sorghum (Sorghum bicolor) $)^{(1)}$.

\begin{tabular}{|c|c|c|c|c|c|}
\hline \multirow[t]{2}{*}{ Fraction } & \multicolumn{4}{|c|}{ Variety } & \multirow{2}{*}{$\begin{array}{c}\text { Coefficient of variation } \\
(\%)\end{array}$} \\
\hline & BRS 506 & BRS 508 & BRS 509 & BRS 511 & \\
\hline & \multicolumn{5}{|c|}{ Production $\left(\mathrm{kg} \mathrm{ha}^{-1}\right)$} \\
\hline Panicle & $2,707.16 \mathrm{a}$ & $2,507.21 b$ & $2,747.11 \mathrm{a}$ & $2,759.00 \mathrm{a}$ & 29.74 \\
\hline Leaf & $420.73 b$ & $960.82 \mathrm{a}$ & $385.60 \mathrm{~b}$ & $399.38 b$ & 8.12 \\
\hline Stem & $19,194.34 b$ & $18,523.70 \mathrm{c}$ & $20,919.47 \mathrm{a}$ & $20,081.21 \mathrm{a}$ & 9.34 \\
\hline \multirow[t]{2}{*}{ Total production } & $22,322.24 b$ & $21,991.74 \mathrm{c}$ & $24,052.19 \mathrm{a}$ & $23,239.60 \mathrm{a}$ & 18.90 \\
\hline & \multicolumn{5}{|c|}{ Crude protein (\% dry matter) } \\
\hline Panicle & $4.29 b$ & $7.65 \mathrm{a}$ & $6.31 \mathrm{ab}$ & $4.51 b$ & 15.24 \\
\hline Leaf & 10.87 & 11.89 & 11.02 & 10.63 & 12.6 \\
\hline Stem & $3.42 \mathrm{ab}$ & $2.84 \mathrm{~b}$ & $4.18 \mathrm{ab}$ & $4.34 \mathrm{a}$ & 15.48 \\
\hline \multirow[t]{2}{*}{ Whole plant } & $4.76 b$ & $5.30 \mathrm{a}$ & $4.78 \mathrm{~b}$ & $5.14 \mathrm{a}$ & 3.91 \\
\hline & \multicolumn{5}{|c|}{ Neutral detergent fiber ( $\%$ dry matter) } \\
\hline Panicle & $73.04 \mathrm{a}$ & $54.37 \mathrm{c}$ & $62.71 \mathrm{bc}$ & $68.55 \mathrm{ab}$ & 6.01 \\
\hline Leaf & $50.35 \mathrm{ab}$ & $50.44 \mathrm{ab}$ & $54.42 \mathrm{a}$ & $49.52 b$ & 3.53 \\
\hline Stem & 38.70 & 37.59 & 36.97 & 39.11 & 10.77 \\
\hline \multirow[t]{2}{*}{ Whole plant } & $49.69 \mathrm{a}$ & $42.16 b$ & $40.93 \mathrm{~b}$ & $41.69 \mathrm{~b}$ & 9.98 \\
\hline & \multicolumn{5}{|c|}{ Acid detergent fiber ( $\%$ dry matter) } \\
\hline Panicle & $41.13 \mathrm{a}$ & $25.88 \mathrm{c}$ & $31.12 \mathrm{bc}$ & $35.74 \mathrm{ab}$ & 7.37 \\
\hline Leaf & $25.29 \mathrm{ab}$ & $24.36 b$ & $28.03 \mathrm{a}$ & $23.16 \mathrm{~b}$ & 4.94 \\
\hline Stem & 20.25 & 20.82 & 18.68 & 21.34 & 16.43 \\
\hline \multirow[t]{2}{*}{ Whole plant } & $28.48 \mathrm{a}$ & $24.42 b$ & $23.64 \mathrm{c}$ & $20.86 \mathrm{~d}$ & 2.21 \\
\hline & \multicolumn{5}{|c|}{ Hemicellulose (\% dry matter) } \\
\hline Panicle & 31.91 & 28.48 & 31.58 & 32.82 & 8.06 \\
\hline Leaf & 25.06 & 26.08 & 26.39 & 26.37 & 3.58 \\
\hline$\underline{\text { Stem }}$ & 18.46 & 18.77 & 18.30 & 17.77 & 11.31 \\
\hline \multirow[t]{2}{*}{ Whole plant } & $21.21 \mathrm{a}$ & $17.75 \mathrm{~d}$ & $20.38 \mathrm{~b}$ & $19.23 \mathrm{c}$ & 1.52 \\
\hline & \multicolumn{5}{|c|}{ Cellulose (\% dry matter) } \\
\hline Panicle & $32.70 \mathrm{a}$ & $19.99 \mathrm{c}$ & $22.72 b c$ & $27.88 \mathrm{ab}$ & 8.25 \\
\hline Leaf & $18.76 \mathrm{ab}$ & $19.82 \mathrm{ab}$ & $21.89 \mathrm{a}$ & $18.05 b$ & 6.52 \\
\hline Stem & 15.23 & 15.45 & 14.14 & 16.87 & 16.56 \\
\hline \multirow[t]{2}{*}{ Whole plant } & $23.64 a$ & $20.49 \mathrm{~b}$ & $20.48 \mathrm{~b}$ & $20.74 b$ & 4.86 \\
\hline & \multicolumn{5}{|c|}{ Lignin (\% dry matter) } \\
\hline Panicle & $7.65 \mathrm{a}$ & $5.35 b$ & $7.56 \mathrm{a}$ & $6.98 \mathrm{ab}$ & 16.21 \\
\hline Leaf & $5.90 \mathrm{a}$ & $3.63 \mathrm{c}$ & $5.13 b$ & $3.99 b$ & 18.23 \\
\hline Stem & $4.62 \mathrm{a}$ & $4.77 \mathrm{a}$ & $3.98 \mathrm{~b}$ & $3.94 b$ & 13.45 \\
\hline \multirow[t]{2}{*}{ Whole plant } & $3.84 \mathrm{a}$ & $3.17 \mathrm{~b}$ & $3.92 \mathrm{a}$ & $3.18 \mathrm{~b}$ & 15.69 \\
\hline & \multicolumn{5}{|c|}{ Digestibility (\% dry matter) } \\
\hline Panicle & $32.30 \mathrm{~b}$ & $62.00 \mathrm{a}$ & $40.50 \mathrm{~b}$ & $36.10 \mathrm{~b}$ & 16.21 \\
\hline Leaf & 56.17 & 55.53 & 49.27 & 52.53 & 6.61 \\
\hline$\underline{\text { Stem }}$ & 65.63 & 63.73 & 65.53 & 60.70 & 10.54 \\
\hline Whole plant & $65.67 \mathrm{c}$ & $70.65 a$ & $65.93 c$ & $67.61 \mathrm{~b}$ & 1.74 \\
\hline
\end{tabular}

${ }^{(1)}$ Means followed by different letters, within rows, differ by Tukey's test, at $5 \%$ probability. 
protein content, which positively affected in vitro DM digestibility; consequently, the use of this cultivar as fresh forage in animal feed could be recommended.

There was no difference in $\mathrm{pH}$ between the studied varieties either at the beginning or at the end of the silage process (Table 2). The average $\mathrm{pH}$ value was 3.64, which can be considered ideal, since, according to Ferreira et al. (2011), $\mathrm{pH}$ values lower than 4.0 indicate the occurrence of lactic acid fermentation that inhibits the growth of undesirable microorganisms, ensuring the quality of the final product. França et al. (2011) obtained values of $\mathrm{pH}$ ranging from 3.9 to 4.3 in the silages of the 1F 305, 0369267,0369255 , and BR 700 forage sorghum varieties. This indicates that the larger content of soluble carbohydrates present in saccharine varieties, when compared to forage varieties, may provide greater production of short-chain organic acids during the ensiling process, which enables a fast and efficient $\mathrm{pH}$ reduction in the ensiled material.

The BRS 511, BRS 508, and BRS 506 varieties presented the highest DM losses, whereas BRS 509 had the lowest one. These results are similar to those obtained by Rodrigues et al. (2002), who found DM losses ranging from 8 to $14 \%$. Regarding gas losses, these did not differ among varieties, with a mean value of $5.98 \%$. This value was greater than the gas losses of $2 \%$ reported by França et al. (2011), when evaluating silage of the 1F 305, 0369 267, 0369 255, and BR 700 forage sorghum varieties.

Saccharine varieties have a succulent stem and, as a result, showed high effluent production (Podkówka
\& Podkówka, 2011), from 310.89 to $521.87 \mathrm{~kg} \mathrm{Mg}^{-1}$ ensiled DM for BRS 509 and BRS 506, respectively. These results are considered high in comparison to the value of $133 \mathrm{~kg} \mathrm{Mg}^{-1}$ observed by França et al. (2011) using forage varieties. This excessive effluent can promote the development of anaerobic bacteria of the genus Clostridium, which produce butyric acid, resulting in the degradation of protein and lactic acid. Furthermore, a significant portion of plant nutrients can be eliminated from the effluent, reducing the quality of the material (Amaral et al., 2008; Silva et al., 2014b).

When comparing the quality of the plants of the first trial (same material used for filling the silo) and of the silages of the second trial, it can be concluded that the more digestible the variety is, the greater the loss of quality will be due to the leaching of nutrients via effluent production. The BRS 508 variety presented the highest coefficient of in vitro DM digestibility before ensiling, and, because of the large production of effluent (393.16 kg Mg-1 DM), the value of digestibility was reduced in $19.29 \%$ of silage produced $(57.02 \%)$. In contrast, BRS 509, which had the worst coefficient of in vitro DM digestibility ( $65.93 \%$ before ensiling) and the lowest production of effluent $(310.89 \mathrm{~kg}$ $\left.\mathrm{Mg}^{-1} \mathrm{DM}\right)$, achieved a reduction of only $6.90 \%$ digestibility (61.35\%) during the ensiling process.

The BRS 506 and BRS 508 varieties generated the greatest amount of effluents and presented the highest values of fibrous fractions, except lignin. In addition, these varieties had the lowest CP values, which shows

Table 2. Values for $\mathrm{pH}$, fermentation losses, and chemical composition of silages produced from four varieties of saccharine sorghum (Sorghum bicolor) ${ }^{(1)}$.

\begin{tabular}{|c|c|c|c|c|c|}
\hline \multirow[t]{2}{*}{ Parameters } & \multicolumn{4}{|c|}{ Variety } & \multirow{2}{*}{$\begin{array}{l}\text { Coefficient of } \\
\text { variation }(\%)\end{array}$} \\
\hline & BRS 506 & BRS 508 & BRS 509 & BRS 511 & \\
\hline pH ensiling & 5.35 & 5.53 & 5.28 & 5.25 & 16.90 \\
\hline $\mathrm{pH}$ opening & 3.60 & 3.68 & 3.64 & 3.67 & 0.47 \\
\hline DM losses $(\%)$ & $10.57 \mathrm{ab}$ & $11.12 \mathrm{ab}$ & $8.87 \mathrm{~b}$ & $16.67 \mathrm{a}$ & 34.88 \\
\hline Gas losses $(\%)$ & 6.16 & 5.94 & 3.74 & 8.10 & 59.24 \\
\hline Effluent losses $\left(\mathrm{kg} \mathrm{Mg}^{-1} \mathrm{DM}\right)$ & $521.87 \mathrm{a}$ & $393.16 b$ & $310.89 d$ & $374.62 c$ & 9.09 \\
\hline Mineral content $(\% \mathrm{DM})$ & $5.26 \mathrm{a}$ & $4.93 \mathrm{ab}$ & $4.48 \mathrm{c}$ & $4.82 \mathrm{bc}$ & 7.91 \\
\hline Crude protein $(\% \mathrm{DM})$ & $4.14 b$ & $4.10 \mathrm{~b}$ & $4.98 \mathrm{a}$ & $4.96 \mathrm{a}$ & 5.81 \\
\hline Neutral detergent fiber ( $\%$ DM) & $47.30 \mathrm{ab}$ & $48.32 \mathrm{a}$ & $43.63 \mathrm{c}$ & $45.70 b$ & 7.45 \\
\hline Acid detergent fiber (\% DM) & $27.60 \mathrm{ab}$ & $27.69 \mathrm{a}$ & $24.01 \mathrm{c}$ & $24.45 b c$ & 11.31 \\
\hline Hemicellulose (\% DM) & 19.70 & 20.63 & 19.61 & 21.24 & 11.00 \\
\hline Cellulose (\% DM) & $21.52 \mathrm{ab}$ & $22.49 \mathrm{a}$ & $18.24 \mathrm{c}$ & $18.88 b c$ & 12.47 \\
\hline Lignin (\% DM) & 5.31 & 4.51 & 5.33 & 5.07 & 18.1 \\
\hline Digestibility (\% DM) & $57.29 \mathrm{~b}$ & $57.02 \mathrm{~b}$ & $61.35 \mathrm{a}$ & $61.16 \mathrm{a}$ & 5.7 \\
\hline
\end{tabular}

${ }^{(1)}$ Means followed by different letters, within rows, differ by Tukey's test, at $5 \%$ probability. DM, dry matter. 
even more the negative effects of effluent production in these varieties of saccharine sorghum.

Despite the mentioned losses, which are unusual when compared to other species of sorghum, the varieties showed an adequate chemical composition from a nutritional point of view, in which some results were superior when compared with the varieties of forage and grain sorghum commonly found. The average levels of $46.30 \% \mathrm{NDF}$ and $59.20 \%$ in vitro DM digestibility obtained in the present study were lower than those reported by Rodrigues et al. (2002) for forage varieties, who observed values of $58.79 \%$ NDF and $52.87 \%$ in vitro DM digestibility.

All varieties presented satisfactory performance (Coan et al., 2007; Podkówka \& Podkówka, 2011; Dias et al., 2014) in the studied parameters, except effluent production, which must be reduced to ensure a more appropriate use of nutrients from the silage produced from the saccharine varieties.

\section{Conclusions}

1. The BRS 511 variety presents higher plant production and nutritional quality.

2. Regarding the fermentation process, the BRS 509 variety presents the lowest fermentative losses and the highest nutritional value of silage.

\section{References}

ALVES, E.M.; PEDREIRA, M. dos S.; AGUIAR, L.V.; COELHO, C.P.; OLIVEIRA, C.A.S. de; SILVA, A.M.P. Silagem de sorgo com e sem tanino em substituição à silagem de milho na alimentação de ovinos: desempenho e características de carcaça. Ciência Animal Brasileira, v.13, p.157-164, 2012. DOI: 10.5216/cab.v13i2.8261.

AMARAL, R.C. do; BERNARDES, T.F.; SIQUEIRA, G.R.; REIS, R.A. Estabilidade aeróbia de silagens do capim-marandu submetidas a diferentes intensidades de compactação na ensilagem. Revista Brasileira de Zootecnia, v.37, p.977-983, 2008. DOI: 10.1590/S1516-35982008000600004.

AMER, S.; SEGUIN, P.; MUSTAFA, A.F. Effects of feeding sweet sorghum silage on milk production of lactating dairy cows. Journal of Dairy Science, v.95, p.859-863, 2012. DOI: 10.3168/ jds.2011-4884.

BERGAMASCHINE, A.F.; PASSIPIÉRI, M.; VERIANO FILHO, W.V.; ISEPONI, O.J.; CORREA, L. de A. Qualidade e valor nutritivo de silagens de capim-marandu (B. brizantha $\mathrm{cv}$. Marandu) produzidas com aditivos ou forragem emurchecida. Revista Brasileira de Zootecnia, v.35, p.1454-1462, 2006. DOI: 10.1590/ S1516-35982006000500027.

COAN, R.M.; REIS, R.A.; GARCIA, G.R.; SCHOCKEN-ITURRINO, R.P.; FERREIRA, D. de S.; RESENDE,
F.D. de; GURGEL, F. do A. Dinâmica fermentativa e microbiológica de silagens dos capins Tanzânia e Marandu acrescidas de polpa cítrica peletizada. Revista Brasileira de Zootecnia, v.36, p.1502-1511, 2007. DOI: 10.1590/S1516-35982007000700007.

DIAS, A.M.; ÍTAVO, L.C.V.; ÍTAVO, C.C.B.F.; BLAN, L.R.; GOMES, E.N.O.; SOARES, C.M.; LEAL, E.S.; NOGUEIRA, E.; COELHO, E.M. Ureia e glicerina bruta como aditivos na ensilagem de cana-de-açúcar. Arquivo Brasileiro de Medicina Veterinária e Zootecnia, v.66, p.1874-1882, 2014. DOI: 10.1590/1678-7349.

DURÃES, F.O.M.; MAY, A.; PARRELLA, R.A. da C. Sistema agroindustrial do sorgo sacarino no Brasil e a participação público-privada: oportunidades, perspectivas e desafios. Sete Lagoas: Embrapa Milho e Sorgo, 2012. 76p. (Embrapa Milho e Sorgo. Documentos, 138).

FERREIRA, D.J.; ZANINE, A.M.; SANTOS, E.M.; LANA, R.P.; SILVA, W.L.; SOUZA, A.L.; PEREIRA, O.G. Perfil fermentativo e valor nutritivo de silagem de capim-elefante inoculada com Streptococcus bovis. Archivos de Zootecnia, v.60, p.1223-1228, 2011. DOI: 10.4321/S0004-05922011000400037.

FRANÇA, A.F. de S.; OLIVEIRA, R. de P.; RODRIGUES, J.A.S.R.; MIYAGI, E.S.; SILVA, A.G. da; PERON, H.J.M.C.; ABREU, J.B.R. de; BASTOS, D. de C. Características fermentativas da silagem de híbridos de sorgo sob doses de nitrogênio. Ciência Animal Brasileira, v.12, p.383-391, 2011. DOI: 10.5216/cab. v12i3.540.

JOBIM, C.C.; NUSSIO, L.G.; REIS, R.A.; SCHMIDT, P. Avanços metodológicos na avaliação da qualidade da forragem conservada. Revista Brasileira de Zootecnia, v.36, p.101-119, 2007. DOI: 10.1590/S1516-35982007001000013.

LOURENÇO, M.E.V.; MASSA, V.M.L.; PALMA, P.M.M.; RATO, A.E.M. Potencialidades do sorgo sacarino [Sorghum bicolor (L.) Moench] para a produção sustentável de bioetanol no Alentejo. Revista de Ciências Agrárias, v.30, p.103-110, 2007.

NASCIMENTO, W.G. do; PRADO, I.N.; JOBIM, C.C.; EMILE, J.C.; SURAULT, F.; HUYGHE, C. Valor alimentício das silagens de milho e de sorgo e sua influência no desempenho de vacas leiteiras. Revista Brasileira de Zootecnia, v.37, p.896-904, 2008. DOI: $10.1590 /$ S1516-35982008000500018.

ORRICO JUNIOR, M.A.P.; ORRICO, A.C.A.; CENTURION, S.R.; SUNADA, N. da S.; LUCAS JUNIOR, J. de. Valor nutritivo do capim Piatã adubado com diferentes doses de biofertilizante. Revista Agrarian, v.6, p.312-319, 2013.

PARRELLA, R.A.C.; SCHAFFERT, R.E. Cultivares. In: MAY, A.; DURÃES, F.O.M.; PEREIRA FILHO, I.A.; SCHAFFERT, R.E.; PARRELLA, R.A.C. (Ed.). Sistema Embrapa de produção agroindustrial de sorgo sacarino para bioetanol: Sistema BRS1G-Tecnologia Qualidade Embrapa. Sete Lagoas: Embrapa Milho e Sorgo, 2012. p.14-22. (Embrapa Milho e Sorgo. Documentos, 139).

PODKÓWKA, Z.; PODKÓWKA, L. Chemical composition and quality of sweet sorghum and maize silages. Journal of Central European Agriculture, v.12, p.294-303, 2011. DOI: 10.5513/ JCEA01/12.2.915.

RODRIGUES FILHO, O.; FRANÇA, A.F. de S.; OLIVEIRA, R. de P.; OLIVEIRA, E.R. de; ROSA, B.; SOARES, T.V.; MELLO, 
S.Q.S. Produção e composição bromatológica de quatro híbridos de sorgo forrageiro [Sorghum bicolor (L.) Moench] submetidos a três doses de nitrogênio. Ciência Animal Brasileira, v.7, p.37-48, 2006. DOI: 10.1590/S1516-35982002000900030.

RODRIGUES, P.H.M.; SENATORE, A.L.; ANDRADE, S.J.T. de; RUZANTE, J.M.; LUCCI, C.S. de; LIMA, F.R. de. Efeitos da adição de inoculantes microbianos sobre a composição bromatológica e perfil fermentativo da silagem de sorgo produzida em silos experimentais. Revista Brasileira de Zootecnia, v.31, p.2373-2379, 2002. DOI: 10.1590/S1516-35982002000900028.

SANTOS, H.G. dos; JACOMINE, P.K.T.; ANJOS, L.H.C. dos; OLIVEIRA, V.A.; OLIVEIRA, J.B. de; COELHO, M.R.; LUMBRERAS, J.F.; CUNHA, T.J.F. Sistema brasileiro de classificação de solos. 2.ed. Rio de Janeiro: Embrapa Solos, 2006. $306 \mathrm{p}$.

SANTOS, R.F. dos; PLACIDO, H.F.; GARCIA, E.B.; CANTÚ, C.; ALBRECHT, A.J.P.; ALBRECHT, L.P.; FRIGO, K.D. de A. Sorgo sacarino na produção de agroenergia. Revista Brasileira de Energias Renováveis, v.4, p.1-12, 2015.
SILVA, C.; SILVA, A.F. da; VALE, W.G. do; GALON, L.; PETTER, F.A.; MAY, A.; KARAM, D. Interferência de plantas daninhas na cultura do sorgo sacarino. Bragantia, v.73, p.438-445, 2014a. DOI: 10.1590/1678-4499.0119.

SILVA, D.J.; QUEIROZ, A.C. de. Análise de alimentos: métodos químicos e biológicos. 3.ed. Viçosa: Ed. da UFV, 2006. 235p.

SILVA, E.T.P. da; GUIMARÃES, K.C.; MARQUES, K.O.; CARVALHO, T.A.; ANTONIO, P.; VIEIRA JUNIOR, M.I.R. Nutritional and fermentation parameters of Xaraés grass silage produced with bacterial additive. Acta Scientiarum. Animal Sciences, v.36, p.265-269, 2014b. DOI: 10.4025/actascianimsci. v36i3.22885.

SOUZA, V.G. de; PEREIRA, O.G.; MORAES, S.A. de; GARCIA, R.; VALADARES FILHO, S. de C.V.; ZAGO, C.P.; FREITAS, E.V.V. Valor nutritivo de silagens de sorgo. Revista Brasileira de Zootecnia, v.32, p.753-759, 2003. DOI: 10.1590/ S1516-35982003000300028.

THE R FOUNDATION. R: The R project for statistical computing. Vienna: The R Foundation, 2012.

Received on August 8, 2014 and accepted on October 15, 2015

Pesq. agropec. bras., Brasília, v.50, n.12, p.1201-1207, dez. 2015 DOI: $10.1590 / \mathrm{S} 0100-204 X 2015001200010$ 